\title{
COMPARATIVE LEAF MORPHOLOGY AND ANATOMY OF SOME NEOTROPICAL PHILODENDRON SCHOTT (ARACEAE) SPECIES
}

\author{
MaŁgorzata Klimko, Magdalena WawrzyŃSKa, Justyna Wiland-SzYmańSKa
}

\author{
M. Klimko, Department of Botany, Poznań University of Life Sciences, Wojska Polskiego 71 C, 60-625 \\ Poznań, Poland, e-mail: klim@up.poznan.pl \\ M. Wawrzyńska, Klaudyna Potocka High School, Zmartwychwstanców 10, 61-501 Poznań, Poland, e-mail: \\ wawrzynska@poczta.onet.pl \\ J. Wiland-Szymańska, Department of Plant Taxonomy, Adam Mickiewicz University of Poznań, Umultowska \\ 89, 61-614 Poznań, Poland, e-mail: wiland@amu.edu.pl
}

(Received: April 03, 2014. Accepted: May 27, 2014)

\begin{abstract}
AвSTRACt. A comparative morphological and anatomical study on the petioles and lamina of 22 taxa (species, subspecies and cultivars) of the genus Philodendron (subgenera Meconostigma, Pteromischum and Philodendron) has been made in order to investigate interspecific differences which may be useful in species identification. All species have bifacial leaves with petioles, amphistomatic with a strongly reduced density of stomata on the adaxial leaf surface. The species differ in the size and shape of their epidermal cells, the distribution and types of stomata and cuticle ornamentation in the lamina, thickness of epicuticular layer, presence or absence of hypodermis, structure of spongy mesophyll, thickness of palisade and spongy mesophyll layers, as well as types of raphides, and in the structure and forms of petioles. A combination of these characters may be useful in species identification. This study shows that there is some variation in petiole and leaf morphological and anatomical characters among the 22 taxa of Philodendron. However, many characters are present in all of them and may be typical of the genus. The study revealed several detailed interesting epidermal and anatomical features that have not previously been reported in the genus.
\end{abstract}

Key Words: petiole, lamina, monocots, morphology, anatomy, Philodendron subgenera Meconostigma, Pteromischum, Philodendron

\section{INTRODUCTION}

With more than 700 species, the genus Philodendron is the second largest genus in the family Araceae after Anthurium Schott (CROAT 1997). This morphologically and ecologically diverse genus is strictly a New World genus, brought from northern Mexico to southern Uruguay (MAYO et al. 1997). The genus, has been initially divided into four subgenera: Euphilodendron, Calostigma, Meconostigma and Sphincterostigma (Sснотт 1832), and later into two subgenera Euphilodendron (=Philodendron) and Meconostigma (ENGLER 1899, KRAUSE 1913), is now subdivided into three subgenera. Pteromischum with 75 species (Grayum 1996), Meconostigma with 15 species (MaYo 1988, 1991, CroAt 1997) and Philodendron with more than 600 species (CROAt 1997) are accepted worldwide (Mayo 1988, Grayum 1990, 1996, Mayo et al. 1997,
Croat 1997, Sakuragui et al. 2005). Two of them, i.e. Meconostigma and Philodendron, are morphologically well defined (MAYO 1990, 1991). Recently the subgenus Meconostigma has been revised (MAYO 1991, Gonçalves \& Salviani 2002) and partial revisions of the subgenera Pteromischum (GRAYUm 1996) and Philodendron (CROAT 1997) have been published. However, no complete revision of the genus has been undertaken since the classification of KRAUSE (1913), which included 222 species of Philodendron. Previous classifications were based on morphological characters mainly concerning the inflorescence, flower and leaf shape. As defined by morphological characters and based on molecular analyses [two ribosomal DNA nuclear markers, internal transcribed spacer (ITS) and external transcribed spacer (ETS), chloroplast intron $r p l 16]$ all the three subgenera are monophyletic (GAUTHIER et al. 2008). According to the results of 
BARABÉ et al. (2002) and TAm et al. (2004), the genus Philodendron would be paraphyletic because the genus Homalomena Schott is nested within Philodendron (subgenus Meconostigma) in their phylogenetic analyses based on chloroplast DNA sequences. The genus Homalomena Schott is morphologically very similar to Philodendron (MAYO et al. 1997). Philodendron is a genus of outstanding horticultural importance and the subgenus Meconostigma includes some very well known ornamental species. Philodendron bipinnatifidium Schott ex Endl., one of the world's most ubiquitous houseplants, has provided a rich source of variation for breeding of different foliage forms. Most of the species popularly known as 'self-headers' belong to this subgenus. In cultivation other very common species also include P. cordatum (Vell) Kunth, P. lacerum (Jacq.) Schott, P. hederaceum (Jacq.) Schoot from the subgenus Philodendron as well as other species and hybrids (MAYO et al. 1997). The purpose of this comparative study is to assess morphological and anatomical variations, potentially useful in species identification, as well as to test validity of the classification of the genus into subgenera and sections.

\section{MATERIAL AND METHODS}

For this study 18 species, one subspecies and three cultivars were examined. Samples were obtained from the greenhouses of the Botanical Garden in Poznań (Poland) (BG-AMU). We included taxa from three subgenera of Philodendron. For the subgenus Philodendron, representatives from five of the nine sections recognised by CROAT (1997) were included (Table 1). For SEM studies mature air dried leaves were coated with gold and examined under a Philips 515 and Zeiss EVO 40 scanning electron microscope at the Electron Microscopy Laboratory, the Faculty of Biology, the Adam Mickiewicz University of Poznań. The sculpture of both surfaces of the lamina was studied with LM on permanent slides. For anatomical studies living material was stored protected in $70 \%$ alcohol. The anatomy of the lamina, midrib and petiole was studied. Transversal sections, $50 \mu \mathrm{m}$ thick, were prepared with a microtome (Leitz). All sections were embedded in glycerin-gelatin. Slides thus prepared were used to describe transverse sections (T.S.) and measured characters (Tables 2-4). The epidermal thickness index (ETI) was calculated as the ratio of adaxial epidermis thickness to abaxial epidermis thickness (Table 4). All measurements were carried out under a light microscope (LM) (Olympus BX 43). Five leaves were examined from each species. The midrib outline was classified using the current terminology described in CROAT \& Bunting (1979). In this paper we followed KeAting (2002) for the description of stomata types, while the terminology of epidermis sculpturing follows BARTHLOTT (1990). The classification of cells and tissues follows the nomenclature proposed by KEATING (2000, 2002) and raphides of calcium oxalate crys-

Table 1. Philodendron specimens used in this study

\begin{tabular}{|c|c|c|c|}
\hline \multirow{2}{*}{ Taxa } & \multirow{2}{*}{ Voucher information } & \multicolumn{2}{|c|}{ Taxonomy } \\
\hline & & subgenus & section \\
\hline Philodendron bipinnatifidum Schott ex Endl. & I-I005-005-0000-6991-4010 & Meconostigma & \\
\hline P. surinamense Schott ex Engl. & I-I005-002-0000-6995-2279 & Pteromischum & Fruticosa \\
\hline P. crassinervium Lindl & I-I005-002-0000-6990-2791 & Philodendron & Baursia \\
\hline P. melanochrysum Linden et Andre & I-I005-002-0000-6994-3999 & Philodendron & Philodendron \\
\hline P. ornatum Schott & I-I005-002-0000-6964-0233 & Philodendron & Philodendron \\
\hline P. hederaceum (Jacq) Schoot var. hederaceum & I-I005-002-0000-6991-1687 & Philodendron & Philodendron \\
\hline P. hederaceum var.. oxycardium (Schott) Croat & I-I005-002-0000-6002-3997 & Philodendron & Philodendron \\
\hline P. bipennifolium Schott & I-I005-002-0000-6991-0616 & Philodendron & ${ }^{*}$ Calostigma \\
\hline P. domesticum G.S. Bunting & I-I005-002-0000-6998-2453 & Philodendron & ${ }^{*}$ Calostigma \\
\hline P. cordatum Kunth ex Schott & I-I005-002-0000-6991-2609 & Philodendron & ${ }^{*}$ Calostigma \\
\hline P. erubescens K. Koch et Augustin & I-I005-002-0000-6979-1543 & Philodendron & ${ }^{*}$ Calostigma \\
\hline P. erubescens K. Koch et Augustin 'Burgundy' & I-I005-001-0000-6996-2326 & Philodendron & ${ }^{*}$ Calostigma \\
\hline P. imbe Schott ex Endl. & I-I005-002-0000-6979-2234 & Philodendron & ${ }^{*}$ Calostigma \\
\hline P. martianum Endl. & I-I005-002-0000-6960-2474 & Philodendron & *Calostigma \\
\hline P. microstictum Standl. et L.O.Williams & I-I005-002-0000-6993-2466 & Philodendron & ${ }^{*}$ Calostigma \\
\hline P. pedatum (Hook) Schoot. & I-I005-002-0000-6992-0784 & Philodendron & Schizophyllum \\
\hline P. squamiferum Poepp. & I-I009-002-0000-6979-2246 & Philodendron & Schizophyllum \\
\hline P. angustisectum Engl. & I-I007-002-0000-6996-2369 & Philodendron & Polytomium \\
\hline P. lacerum (Jacq.) Schott & I-I005-002-0000-6988-2577 & Philodendron & Polytomium \\
\hline P. pinnatifidum (Jacq.) Schott & I-I005-002-0000-6959-2440 & Philodendron & Polytomium \\
\hline$P . \times$ corsinianum Senoner & I-I005-005-0000-6992-2637 & & \\
\hline P. 'Imperial Green' & I-I005-002-0000-6995-2256 & & \\
\hline
\end{tabular}

*Now called sec. Macrobelium according to SAKURAGUI et al. 2005. 
tals follows Turpin (1836) and Keating (2003, 2004 a). The interactions among quantitative features of stomata and lamina were tested using Pearson's correlation coefficient.

\section{RESULTS}

\section{PETIOLE TRANSVERSE SECTION (T. S.) (TABLE 2, FIG. 1)}

Outline: the outline varies from rounded in Philodendron surinamense, $P$. cordatum, $P$. lacinatum, $P$. anguisectum and $P$. lacerum, oval in $P$. crassinervium, $P$. bipennifolium (Fig. 1 A), $P$. pinnatifidum and $P . \times$ corsianum with a small channel in $P$. hederaceum var. hederaceum (Fig. 1 B) or without a channel, hemicylindrical in $P$. erubescens 'Burgundy' (Fig. 1 C), D-shaped in Philodendron 'Imperial Green' and in P. ornatum (Fig. 1 D, G), flattened adaxially in P. bipinnatifidium (Fig. 1 E) $P$. erubescens, $P$. martianum to $\mathrm{C}$-shaped in $P$. melanochrysum, P. domesticum (Fig. 1 I), P. imbe (Fig. $1 \mathrm{H}$ ) and P. microstictum. D-shaped petioles have their lateral margins weakly to prominently raised with the marginal rib either acute or obtuse and C-shaped broadly or narrowly sulcate adaxially with a sharply angled margin. Abaxial petiole rounding is observed in all the taxa.
Cuticle smooth and moderately thickened. Epidermis of small cells level or rounded on the surface and inner walls rounded to angular. Most species have a glabrous petiole surface, but there are conspicuous exceptions. Two species, $P$. ornatum and $P$. squamniferum, have "scaly petioles". In P. ornatum they are reduced to a small protuberance (Fig. $1 \mathrm{G}$ ), in $P$. squamniferum a small protuberance and trichomelike scales are found. Hypodermis: absent in seven species (Table 2) or present of 1-4 layers on adaxial side (Fig. 1 G, H, I). Collenchyma: beneath the epidermis or hypodermis as a continuous band of 3-13 angularly thickened layers (Fig. 1).

Chlorenchyma: beneath the epidermis or up to five rows of cells inside collenchyma (Fig. 1). Ground tissue of various sizes of parenchyma cells among numerous small to medium-sized air cavities. Vascular bundles numerous and scattered, mostly oriented with phloem facing perimeter (Fig. 1). Xylem of 1-3 protoxylem cells per bundle, with spiral to angular thickening and occasionally one metaxylem element. Sclerenchyma: fibers forming phloem cap usually not fully surrounding laterally. In P. bipinnatifidium and $P$. martianum fiber caps surrounding xylem and phloem. Calcium oxalate crystals are most frequently represented by druses (Fig. 1). Druses present subepidermally and in cells bordering air cavities. Small groups of prismatic crystals occur in ground

Table 2. Petiole characters of some Philodendron taxa

\begin{tabular}{|c|c|c|c|c|c|c|}
\hline Taxa & $\begin{array}{l}\text { Length } \\
\text { of petiole } \\
(\mathrm{mm})\end{array}$ & $\begin{array}{c}\text { Width } \times \text { thick- } \\
\text { ness } \\
(\mathrm{mm})\end{array}$ & Outline of the petiole in T.S. & $\begin{array}{l}\text { Number of } \\
\text { hypodermis } \\
\text { layer }\end{array}$ & $\begin{array}{c}\text { Number of } \\
\text { collenchyma } \\
\text { layer }\end{array}$ & $\begin{array}{l}\text { Calcium } \\
\text { oxalate } \\
\text { crystals }\end{array}$ \\
\hline Philodendron bipinnatifidum & $32-102$ & $14.0 \times 12.0$ & flattened adaxially & - & $12-18$ & $\mathrm{R}, \mathrm{S}, \mathrm{D}$ \\
\hline P. surinamense & $3-10$ & 2.2 & rounded & - & $3-4$ & $\mathrm{R}, \mathrm{S}, \mathrm{D}$ \\
\hline P. crassinervium & $4-11$ & $4.4 \times 4.0$ & oval & - & 3 & S, D \\
\hline P. melanochrysum & $3-11$ & $2.2 \times 1.2$ & C-shaped & $1-2$ & $3-4$ & $\mathrm{~S}, \mathrm{D}, \mathrm{P}$ \\
\hline P. ornatum & $12-35$ & $4.6 \times 3.8$ & irregular, flattened & $1-2$ & (4) 5-8 & $\mathrm{S}, \mathrm{D}, \mathrm{P}$ \\
\hline P. hederaceum var. hederaceum & $3-8$ & $5.0 \times 3.5$ & rounded with small channel & 2 & $3-4(5)$ & $\mathrm{S}, \mathrm{D}, \mathrm{P}$ \\
\hline P. hederaceum var. oxycardium & $3-14$ & $2.2 \times 2.0$ & slighlty flattened & $1-2$ & 4 & $\mathrm{R}, \mathrm{S}, \mathrm{D}, \mathrm{P}$ \\
\hline P. bipennifolium & $5-22$ & $4.4 \times 4.6$ & oval & 1 & $4-5$ & S, D \\
\hline P. domesticum & $14-23$ & $6.0 \times 7.0$ & C-shaped & $2-3$ & $3-4$ & $\mathrm{R}, \mathrm{S}, \mathrm{D}, \mathrm{P}$ \\
\hline P. cordatum & $13-47$ & 6.5 & rounded & 1 & $4-7$ & $\mathrm{R}, \mathrm{S}, \mathrm{D}$ \\
\hline P. erubescens & $8-40$ & 7.0 & flattened adaxially & - & $4-5$ & S, D \\
\hline P. erubescens 'Burgundy' & $10-25$ & $5.0 \times 5.2$ & hemicylindrical & - & $6-7$ & $\mathrm{~S}, \mathrm{D}, \mathrm{P}$ \\
\hline P. imbe & $11-29$ & $5.0 \times 5.3$ & C-shaped & $3-4$ & $5-6$ & S, D \\
\hline P. martianum & $13-37$ & $26.0 \times 20.0$ & flattened adaxially & - & $6-12$ & S, D \\
\hline P. microstictum & $2-12$ & $3.4 \times 2.4$ & C-shaped & 2 & $4-5$ & $\mathrm{R}, \mathrm{S}, \mathrm{D}$ \\
\hline P. pedatum & $10-27$ & 4.3 & rounded & 1 & $5-6$ & $\mathrm{R}, \mathrm{S}, \mathrm{D}, \mathrm{P}$ \\
\hline P. squamiferum & $9-20$ & 3.2 & irregular, rounded & $2-3$ & $4-5$ & $\mathrm{R}, \mathrm{S}, \mathrm{D}, \mathrm{P}$ \\
\hline P. angustisectum & $3-33$ & 8.2 & rounded & 1 & $4-5$ & $\mathrm{R}, \mathrm{S}, \mathrm{D}$ \\
\hline P. lacerum & $12-35$ & 8.0 & rounded & $1-2$ & $3-8$ & S, D \\
\hline P. pinnatifidum & $27-75$ & $13.0 \times 12.0$ & oval & 1 & $12-13$ & $\mathrm{R}, \mathrm{S}, \mathrm{D}, \mathrm{P}$ \\
\hline$P . \times$ corsinianum & $21-55$ & $9.0 \times 8.3$ & oval & $2-3$ & $10-12$ & $\mathrm{R}, \mathrm{S}, \mathrm{D}, \mathrm{P}$ \\
\hline P. 'Imperial Green' & $6-27$ & $11.5 \times 8.2$ & D-shaped & - & $4-7$ & $\mathrm{R}, \mathrm{S}, \mathrm{D}, \mathrm{P}$ \\
\hline
\end{tabular}

“-” absence of hypodermis layer, R - raphide, S - styloid, D - druse, P - prism, T.S. - transverse section. 


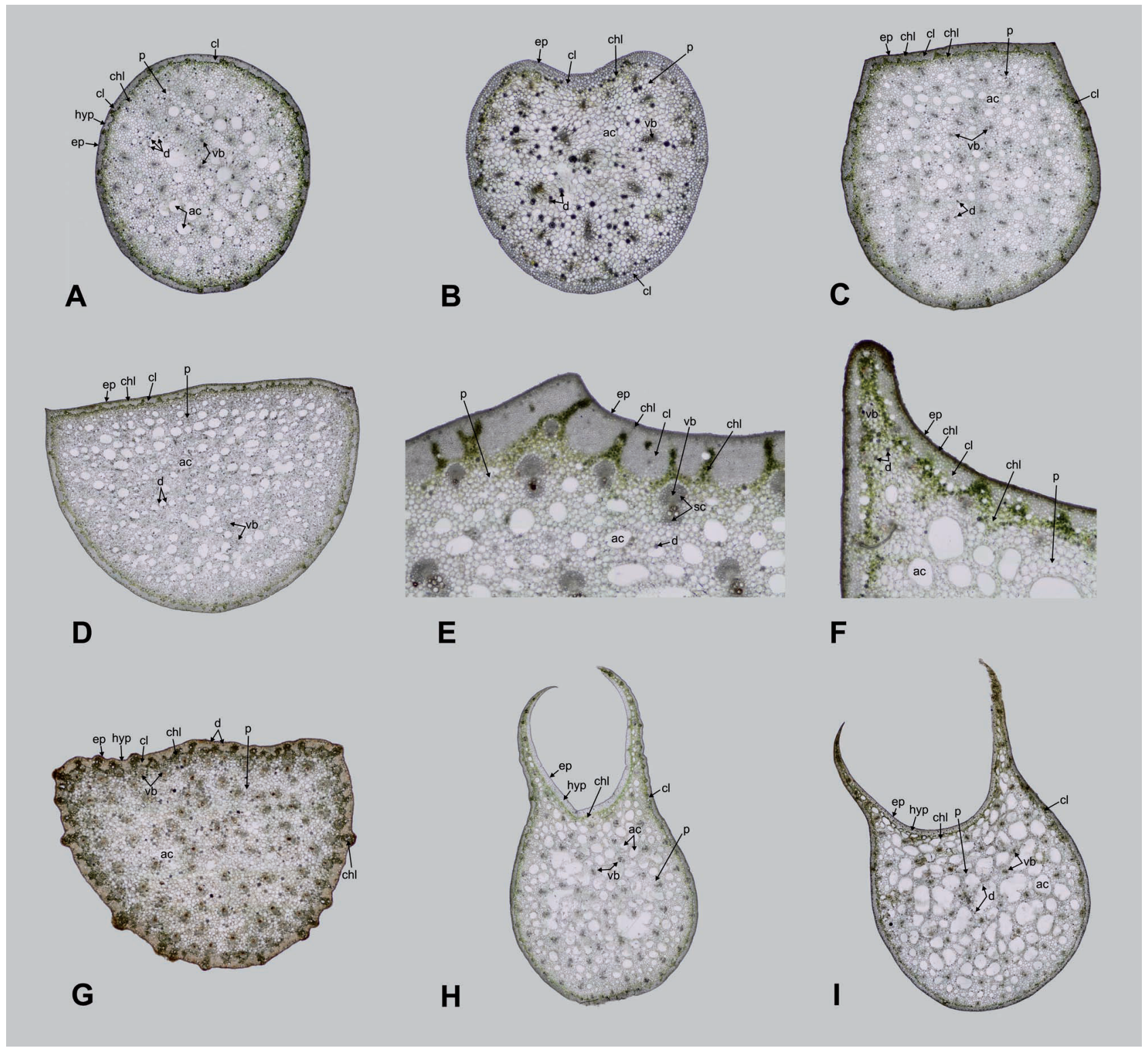

Fig. 1. Petiole transverse sections (T.S.) in some Philodendron taxa illustrating the forms and general anatomy. A $-P$. bipennifolium, B - P. hederaceum var. hederaceum, C - P. erubescens 'Burgundy', D - P. 'Imperial Green'. E - P. bipinnatifidium. Part of marginal petiole on adaxial side, F - P. martianum. Part of marginal petiole on adaxial side, G - P. ornatum, $\mathrm{H}-P$. imbe, I - P. domesticum; ep - epidermis, hyp - hypodermis, cl - collenchyma, chl - chlorenchyma, $\mathrm{p}$ - parenchyma, vb vascular bundle, ac - air cavities, $\mathrm{d}$ - druses

tissue. Single styloids occur individually within cells. Raphides (one to several) that form in bundles are occasionally found in T.S. of petioles. Cell types may be idioblastic and become wide, spindle-shaped and biforine-shaped.

\section{LAMINA SURFACE (TABLE 3, FIGS 2-5)}

The shape of epidermal cells is similar on both surfaces. The cells are irregular or regularly polygonal (tetragonal, pentagonal and hexagonal), and more or less elongated on the midrib and margin, with straight or straight to slightly undulate, raised anticlinal walls and concave or convex periclinal walls. The anticlinal walls are thin or thick (Fig. 4
B, C, E). Stomata are found on both surfaces (Figs 2,3 , arrows), but at the adaxial surface restricted to the midrib and margins (Figs $2 \mathrm{~A}, \mathrm{C}, \mathrm{E}, \mathrm{G} ; 3 \mathrm{~A}$, $\mathrm{C}, \mathrm{E})$. Because only a few stomata were present on the adaxial epidermis it was not possible to describe them in those taxa. The mean number of stomata per $1 \mathrm{~mm}^{2}$ on the abaxial surface is variable among the taxa, ranging from 4.66 to 21.53. Stomata types (Fig. 4) observed mainly on the abaxial surface are: brachyparacytic (Fig. 4 A), brachypara-tetracytic (Fig. 4 C), brachyparahexacytic (Fig. 4 B, E), amphibrachy-paracytic (Fig. $4 \mathrm{D}$ ) and a rare anomocytic type in P. imbe (Fig. 4 F) and P. erubescens 'Burgundy'. They are elliptical in shape, generally longer than wide. The main stomatal length varied from 21.24 
Table 3. Comparison of selected abaxial epidermal features of some Philodendron taxa

\begin{tabular}{|c|c|c|c|c|c|c|}
\hline \multirow[b]{2}{*}{ Taxa } & \multicolumn{6}{|c|}{ Characters } \\
\hline & $\begin{array}{l}\text { length of } \\
\text { stomata } \\
(\mu \mathrm{m})\end{array}$ & $\begin{array}{l}\text { width of } \\
\text { stomata } \\
(\mu \mathrm{m})\end{array}$ & $\begin{array}{l}\text { density of } \\
\text { stomata } \\
\left(\mathrm{n} / \mathrm{mm}^{2}\right)\end{array}$ & $\begin{array}{l}\text { stomatal } \\
\text { types }\end{array}$ & $\begin{array}{l}\text { cuticular orna- } \\
\text { mentation on the } \\
\text { subsidiary cells } \\
\text { of stomata }\end{array}$ & $\begin{array}{l}\text { cuticular } \\
\text { ornamentation } \\
\text { on the midrib }\end{array}$ \\
\hline Philodendron bipinnatifidum & 29.83 & 14.17 & 21.23 & $\mathrm{Bp}$ & - & smooth \\
\hline P. surinamense & 28.80 & 12.96 & 9.06 & $\mathrm{Bh}$ & - & smooth \\
\hline P. crassinervium & 27.99 & 11.47 & 13.86 & Bp & - & smooth \\
\hline P. melanochrysum & 27.31 & 10.17 & 11.86 & $\mathrm{Bh}$ & - & smooth/rugulate \\
\hline P. ornatum & 21.24 & 10.21 & 21.53 & $\mathrm{Ap}, \mathrm{Bh}$ & - & smooth \\
\hline P. hederaceum var. hederaceum & 24.61 & 12.69 & 4.66 & $\mathrm{Bh}, \mathrm{Bt}$ & - & smooth \\
\hline P. hederaceum var. oxycardium & 27.09 & 10.53 & 15.10 & Ap, Bp & + & rugulate/striate \\
\hline P. bipennifolium & 23.67 & 8.19 & 17.00 & Ap & + & rugulate \\
\hline P. domesticum & 25.56 & 9.36 & 9.70 & Ap & + & smooth \\
\hline P. cordatum & 35.59 & 12.55 & 10.43 & $\mathrm{Ap}, \mathrm{Bh}$ & + & rugulate/striate \\
\hline P. erubescens & 27.13 & 9.18 & 14.40 & $\mathrm{Bh}$ & + & rugulate/striate \\
\hline P. erubescens 'Burgundy' & 26.91 & 10.03 & 13.26 & A & + & rugulate/striate \\
\hline P. imbe & 24.03 & 9.36 & 7.00 & A, Ap & + & rugulate \\
\hline P. martianum & 29.56 & 8.37 & 9.93 & $\mathrm{Bh}$ & - & smooth \\
\hline P. microstictum & 33.79 & 11.11 & 7.56 & Ap & + & smooth \\
\hline P. pedatum & 23.44 & 8.32 & 12.83 & $\mathrm{Ap}, \mathrm{Bh}$ & + & smooth \\
\hline P. squamiferum & 26.46 & 9.67 & 16.96 & $\mathrm{Bh}$ & + & smooth/rugulate \\
\hline P. angustisectum & 25.33 & 7.96 & 14.86 & Ap & - & rugulate/striate \\
\hline P. lacerum & 28.75 & 11.92 & 9.76 & Ap & + & smooth/rugulate \\
\hline P. pinnatifidum & 26.82 & 11.61 & 16.53 & $\mathrm{Bh}$ & + & striate \\
\hline P. $\times$ corsinianum & 23.80 & 8.23 & 20.10 & $\mathrm{Ap}, \mathrm{Bh}$ & + & smooth \\
\hline P. 'Imperial Green' & 28.30 & 9.99 & 9.80 & $\mathrm{Bh}$ & + & striate \\
\hline
\end{tabular}

A - anomocytic, Ap - amphibrachyparacytic, Bh - brachyparahexacitic, Bt - brachyparatetracitic, Bp - brachyparacitic, "-" - absence of cuticular ornamentation on the subsidiary cells of stomata, +- presence of cuticular ornamentation on the subsidiary cells of stomata.

$\mu \mathrm{m}$ to $33.79 \mu \mathrm{m}$ and width from $7.96 \mu \mathrm{m}$ to 14.17 $\mu \mathrm{m}$. It results from the calculated Pearson's correlation coefficients that length of stomata is correlated with their width.

The epidermal cells are covered by cuticle. The cuticle of lamina is generally smooth. The striations are more or less irregular in orientation, radiating from guard cells (Figs $3 \mathrm{~B}$; $4 \mathrm{C}-\mathrm{F}$ ). In the midrib cuticular ornamentation is smooth (Fig. $5 \mathrm{~A}$ ), rugulate (Fig. $5 \mathrm{~B}, \mathrm{C}$ ) or rugulate/striate (Fig. $5 \mathrm{D}$, arrows), or thickening of the smooth cuticle is observed on the elongated walls (Figs $2 \mathrm{G}, \mathrm{H} ; 5 \mathrm{~A}$, arrows). Cuticular, irregular protrusions and wart-like protrusions were found on the periclinal walls (Figs $2 \mathrm{C}, \mathrm{D} ; 3 \mathrm{E}, \mathrm{D}$ ). Epicuticular waxes on both epidermal cells are similar, forming platelets (Fig. 2 D), granules and flakes in Philodendron 'Imperial Green'.

\section{LAMINA TRANSVERSE SECTION (T.S.) (TABLE 4, FIG. 6)}

Cuticle: Cuticle in most taxa on the adaxial surface is thicker than the cuticle on the abaxial surface. In $P$. crassinervium, $P$. domesticum, and P. microstictum it is reverse and in P. squamiferum the cuticle on the adaxial surface is as thick as the cuticle on the abaxial surface. The average thickness of the epicuticular layer ranged from 2.5 to $5.3 \mu \mathrm{m}$ on the adaxial surface and from 2.1 to $5.7 \mu \mathrm{m}$ on the abaxial surface. In $P$. martianum the cuticular layer is the thickest on the adaxial (Fig. 6 B) and abaxial surfaces.

Epidermis: In all taxa the leaf epidermis consists of a single layer (Fig. 6 A-E). The anticlinal walls are straight or straight and slightly repand (Fig. $6 \mathrm{D}$ ) and the outer periclinal walls are flat (Fig. 6 B, C, D) or convex (papillate), e.g. in P. surimanense (Fig. 6 F), $P$. hederaceum var. oxycardium and $P$. melanochrysum (Fig. 6 E). The epidermal cells are rectangular (Fig. 6 A-E) only in P. lacinatum, while epidermal cells on the abaxial surface are square. The average thickness of anticlinal walls ranged from $0.81 \mu \mathrm{m}$ to $3.24 \mu \mathrm{m}$ on the adaxial epidermis and from $0.77 \mu \mathrm{m}$ to $3.49 \mu \mathrm{m}$ on the abaxial epidermis. Significant differences in some species are observed in the size (height) of epidermal cells with (Fig. 6 A, B) or without hypodermis (Fig. 6 C, D, E). The average height of epidermal cells with hypodermis ranged from $23.8 \mu \mathrm{m}$ to $38 \mu \mathrm{m}$ on the adaxial surface and from $17.7 \mu \mathrm{m}$ to $36.9 \mu \mathrm{m}$ on the abaxial surface. The average height of epidermal cells without hypodermis ranged from $17.1 \mu \mathrm{m}$ to $82.3 \mu \mathrm{m}$ on the adaxial surface and from $21.1 \mu \mathrm{m}$ to $67.6 \mu \mathrm{m}$ on the abaxial surface. Significant differences between the examined species are found in the shape of epidermal cells in T.S. The reciprocal proportion of the height and width in epidermal cells varies within examined species from 0.85 to 1.5 on 

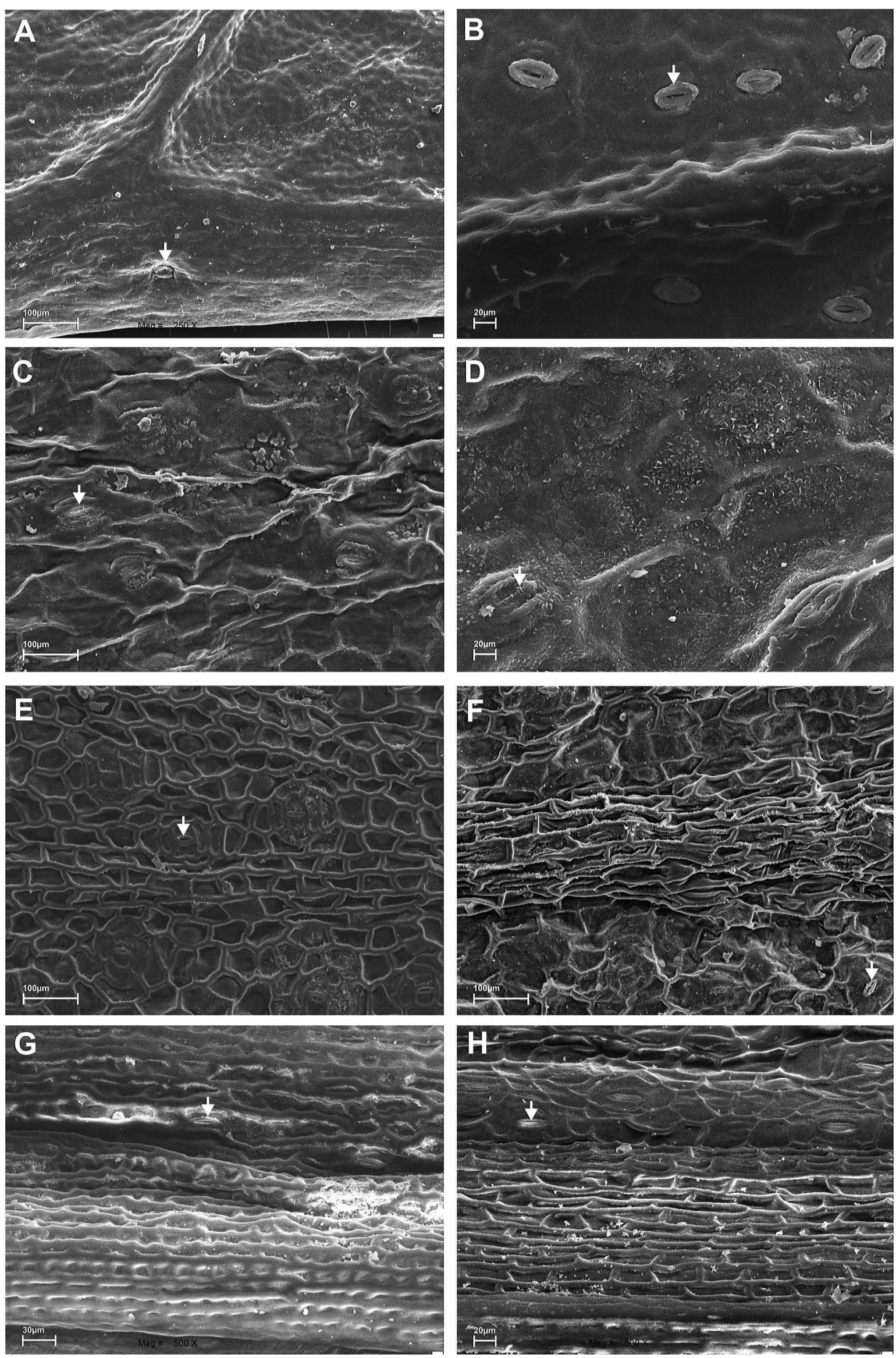

Fig. 2. SEM. Surface view of the adaxial (on the left) and abaxial (on the right) epidermis of Philodendron: A, B - P. bippinatifidium, C, D - P. crassinervium, E, F-P. melanochrysum, G, H - P. bipennifolium (note stomata arrows) 
the adaxial epidermis and from 0.68 to 1.1 on the abaxial epidermis. The adaxial epidemis is thicker than the abaxial epidermis (ETI $>1$ ) in most examined taxa, except for P. bipinnatifidium, P. domesticum, $P$. erubescens 'Burgundy', P. martianum, $P$. imbe, $P$. angustisectum and Philodendron 'Imperial Green', where ETI $<1$. Guard cells are typically level with the other epidermal cells. Leaf thickness as well as leaf epidermis thickness differed significantly between the taxa. There is no correlation between epidermis thickness and leaf thickness. Leaf thickness of the lamina varied from $165.3 \mu \mathrm{m}$ to $463.7 \mu \mathrm{m}$.
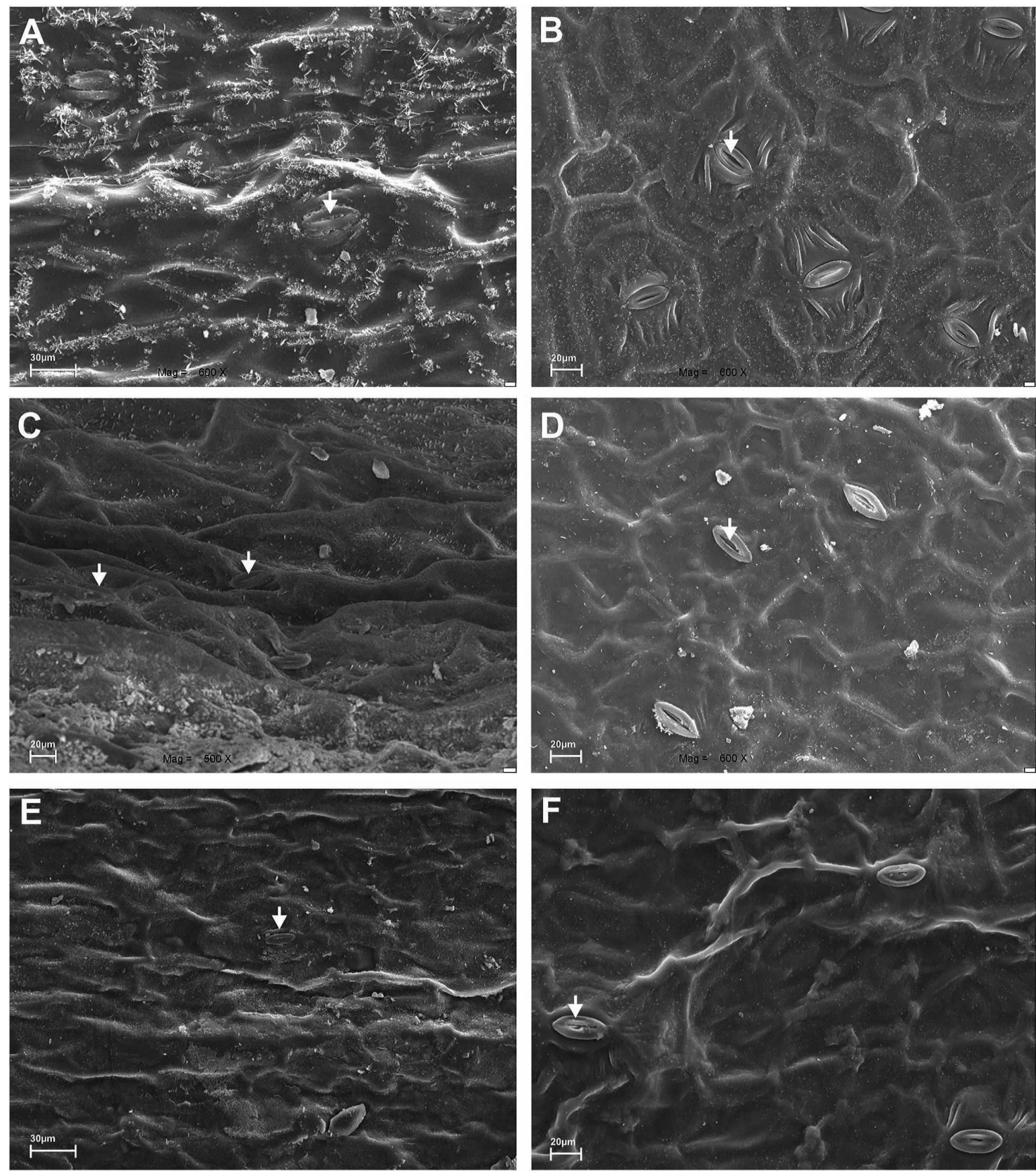

Fig. 3. SEM. Surface view of the abaxial (on the left) and abaxial (on the right) epidermis of Philodendron: A, B - P. cordatum, C, D - P. imbe, E, F - P. squamiferum (note stomata arrows)
Hypodermis: absent (Fig. 6 C, D, E) or present beneath epidermis as 1-2 layers (Fig. 6 B) or 1-4 layer (Fig. 6 A) interrupted by palisade mesophyll on both surfaces or only on the abaxial surface.

Mesophyll: The mesophyll is bifacial, with a thicker spongy layer from 82.2 to $284 \mu \mathrm{m}$ below the palisade (Fig. 6 A-E). The spongy mesophyll has a distinctive structure: with intercellular spaces (Fig. $6 \mathrm{C}$ ) and without them (Fig. $6 \mathrm{~A}, \mathrm{D}, \mathrm{E})$. The palisade parenchyma is found in 1-3 rows in the adaxial part of the leaf blade. Most frequently palisade cells are 2-3 layers and their thickness varies from 36.4 to $79.9 \mu \mathrm{m}$.
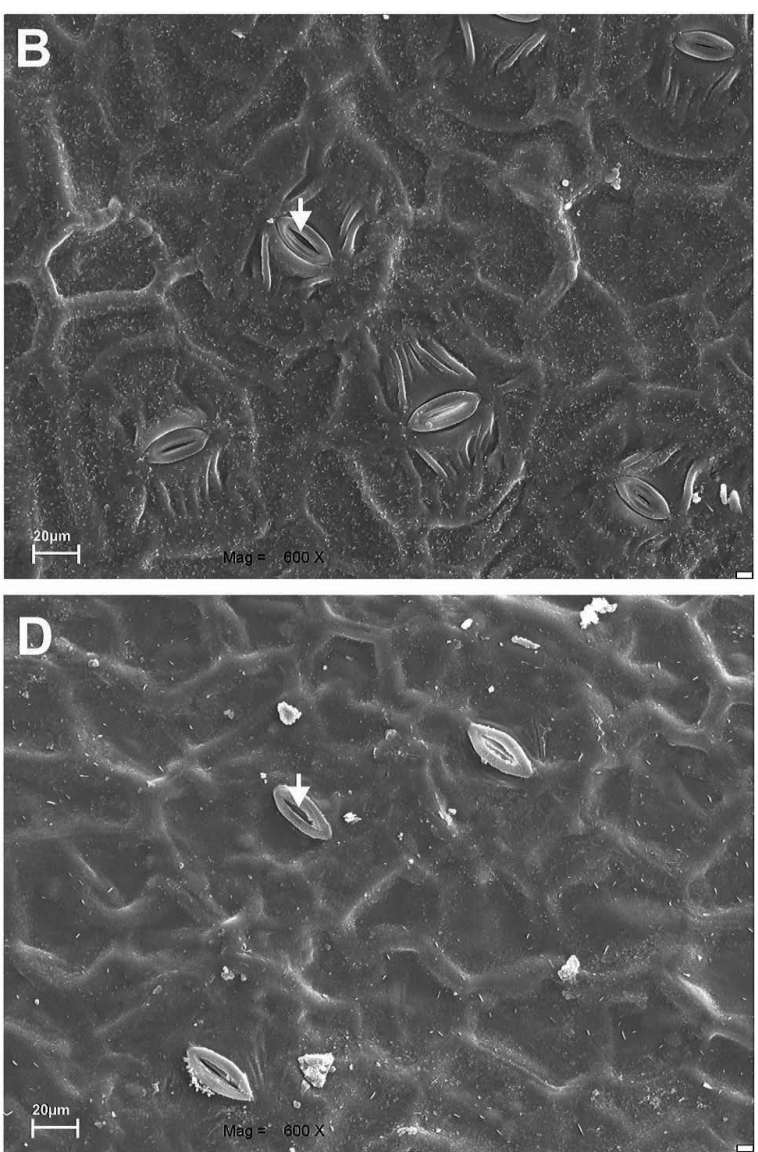
Vascular bundle: In T.S. of lamina vascular bundles are collateral, more elliptic, with proto- and metaxylem with the fiber cap above phloem and xylem. The xylem faces towards the adaxial leaf surface, while the phloem faces the abaxial epidermis.

Midrib: The midrib outline of the lamina in T.S. varies from flat, slightly convex (Fig. 6 F, G) to slightly sunken (Fig. $6 \mathrm{H}$ ) on the adaxial surface. The abaxial midribs of Philodendron exhibit less variability varying from slight to highly convex. On the adaxial surface of the midrib the palisade parenchyma is usually interrupted by a hypodermis or collenchymatous tissue (Fig. 6 G). However, typical apical collenchyma cells are found only in the abaxial region of the midrib (Fig. 6 F, G, H). In the midrib several vascular bundles are found. The large air cavities in the midrib are separated by uniseriate portions of ground tissue (Fig. $6 \mathrm{G}$ ).

Calcium oxalate crystals are represented by raphides, styloids, druses, prisms and crystal sand. The leaves of Philodendron demonstrate the presence of three distinctive raphide crystal types: thin-walled spindle-shaped cells (Sb), biforine (B) and wide cells (W). Druses are found more frequently in the pal-
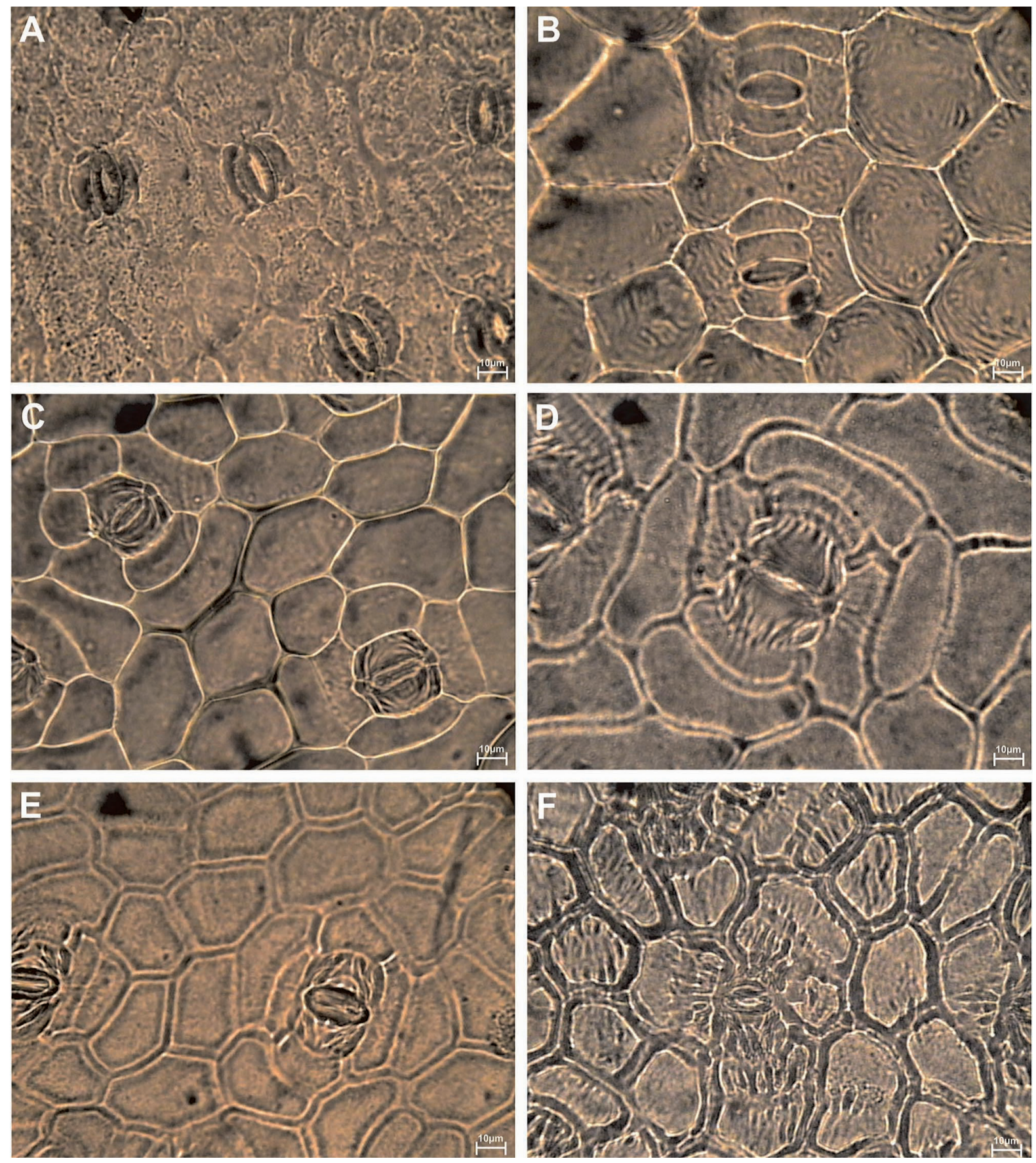

Fig. 4. LM. Surface view of the abaxial epidermis in some Philodendron species: A - P. bipinatifidium. Brachyparacytic stomata, B - P. surinamense. Brachyparahexacytic stomata, C - P. hederaceum var. hederaceum. Brachyparatetracytic stomata, D P. cordatum. Amphibrachyparacytic stoma, E - P. erubescens. Brachyparahexacytic stomata, F - P. imbe. Anomocytic stoma 

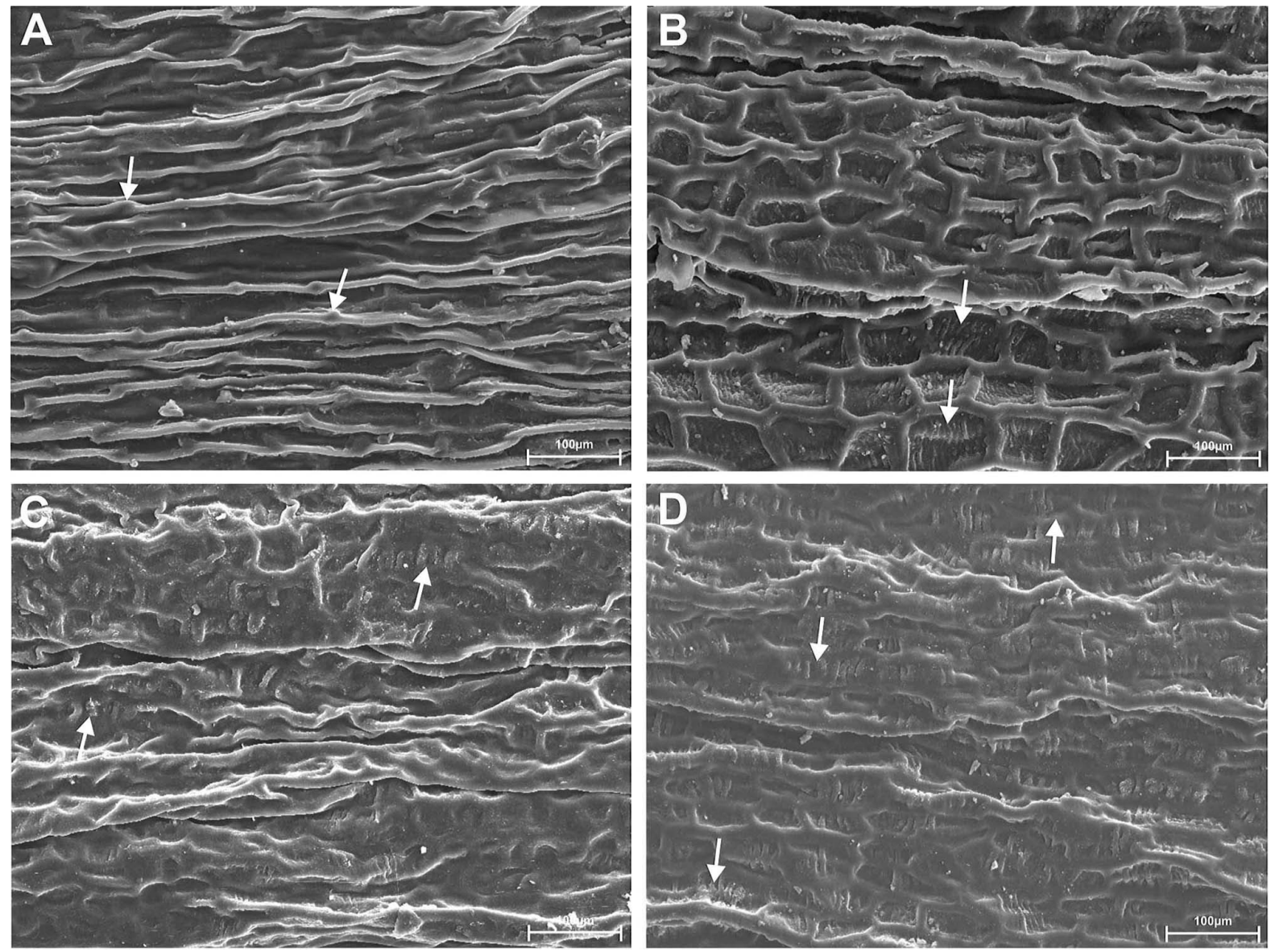

Fig. 5. SEM. Cuticular ornamentation on the midrib in Philodendron species: A - P. crassinervium. Cuticle smooth, thickening on elongated walls, B - P. bipennifolium, C - P. imbe. Cuticle rugulate, D - P. angustisectum. Cuticle rugulate/striate

isade mesophyll layer, hypodermis, collenchyma, ground tissue and rare in epidermis. Raphides are found more often in the spongy mesophyll and in aerenchyma tissue in the midrib. Crystals are found in the midrib in most taxa. Secretion (resin) canals are present in leaves of all species, being found in the mesophyll of lamina and in collenchyma of midribs. They consist of a schizogenous space. Hydathodes and laticifers are present, but detailed studies have not been conducted. Starch grains were not observed in the petiole or the midrib.

\section{DISCUSSION}

Here we showed that some morphological and anatomical characters of petioles and leaves are taxonomically useful for discriminating Philodendron taxa. Regarding $P$. ornatum, $P$. squamniferum, $P$. erubescens and $P$. pinnatifidium our results differ with those of Gauthier et al. (2008) in petiole outline. Cuticular features of the leaf surface cells proved to be of great diagnostic value. It should be noted in ornamentation patterns. Aroid species predominantly show smooth cuticles without ornamentation (KeATING 2002). The species analysed here have smooth cuticle on both surfaces of the lamina, but striped cuticular ornamentation was present on the subsidiary cells of stomata. On the midrib of cuticular ornamentation on the periclinal walls is smooth, rugulate or rugulate /striate or thickening of the smooth cuticle on the elongated walls. In some taxa outer periclinal walls have small irregular protrusions or wart-like elevations. For the first time a detailed description of the surface epidermal leaf of Philodendron was made. Absolute micro morphological diagnostic characters of subgenera and sections levels are absent. The number and distribution of the subsidiary cells from the stomata vary significantly for the Araceae. KEATING (2002) reports brachyparacytic stomata and its variations and the rare type for the Araceae - anomocytic (GreAr 1973). The species analysed here have brachyparacytic, brachypara-tetra, hexacytic and amphibrachy-paracytic types. The anomocytic type was found in P. imbe and P. erubescens 'Burgundy'. The stomatal structure in species of the subgenus Meconostigma were studied by Dilcher \& Daghlian (1977) and Grau (1983). Dilcher \& Daghlian (1977) reported that Philodendron of the subgenus Meconostigma leaves are amphistomatic and hypostomatic. GraU (1983) found that $P$. bipinnatifidium (subgenus Meconostigma) had hypostomatic leaves with the paracytic stomata. In the subgenus Pteromischum (P. surinamense) leaves are hypostomatic with paracytic stomata (GraYum 1996). According to Croat (1997), in the subgenus 
Table 4. Comparison of selected anatomical features of some Philodendron taxa

\begin{tabular}{|c|c|c|c|c|c|c|c|c|c|c|c|c|c|}
\hline \multirow{3}{*}{ Taxa } & \multicolumn{13}{|c|}{ Characters } \\
\hline & \multirow[t]{2}{*}{$\begin{array}{c}\text { leaf } \\
\text { thick- } \\
\text { ness } \\
(\mu \mathrm{m}) \\
\text { lamina }\end{array}$} & \multicolumn{2}{|c|}{$\begin{array}{c}\text { epicuticular } \\
\text { layer thick- } \\
\text { ness } \\
(\mu \mathrm{m})\end{array}$} & \multirow[t]{2}{*}{ ETI } & \multicolumn{2}{|c|}{$\begin{array}{l}\text { height/width } \\
\text { ratio of } \\
\text { epidermal } \\
\text { cells }\end{array}$} & \multicolumn{2}{|c|}{$\begin{array}{l}\text { hypoder- } \\
\text { mis } \\
\text { layer }\end{array}$} & \multirow{2}{*}{$\begin{array}{c}\text { palisade } \\
\text { meso- } \\
\text { phyll } \\
\text { layer }\end{array}$} & \multirow[t]{2}{*}{$\begin{array}{l}\text { spongy } \\
\text { meso- } \\
\text { phyll } \\
\text { layer }\end{array}$} & \multirow[t]{2}{*}{$\begin{array}{l}\text { raphide } \\
\text { type }\end{array}$} & \multirow[t]{2}{*}{ druse } & \multirow[t]{2}{*}{ styloid } \\
\hline & & Ad & $\mathrm{Ab}$ & & Ad & $\mathrm{Ab}$ & Ad & $\mathrm{Ab}$ & & & & & \\
\hline Philodendron bipinnatifidum & 165.3 & 5.3 & 3.8 & 0.97 & 0.96 & 0.77 & Ih2-4 & Ih1 & $1-2$ & $6-8$ & B & + & + \\
\hline P. surinamense & 229.1 & 2.7 & 2.2 & 1.16 & 1.03 & 0.79 & - & - & $2-3$ & $5-6$ & $\mathrm{Sb}$ & + & + \\
\hline P. crassinervium & 234.0 & 2.7 & 3.4 & 1.09 & 1.06 & 0.96 & - & - & 2 & 7 & $\mathrm{Sb}$ & + & + \\
\hline P. melanochrysum & 256.1 & 3.8 & 3.1 & 1.13 & 1.06 & 0.85 & - & - & $1-2$ & $4-5$ & $\mathrm{~B}$ & + & + \\
\hline P. ornatum & 216.2 & 3.5 & 2.9 & 1.33 & 1.09 & 0.94 & - & - & $2-3$ & $5-6$ & B & + & + \\
\hline P. hederaceum var. hederaceum & 277.8 & 4.3 & 3.0 & 1.21 & 1.36 & 1.05 & - & - & $1-2$ & $4-5$ & W & + & + \\
\hline P. hederaceum var. oxycardium & 242.3 & 2.5 & 2.1 & 1.35 & 0.97 & 0.86 & - & Ih 1 & $2-3$ & $5-6$ & B & + & + \\
\hline P. bipennifolium & 272.0 & 3.1 & 2.6 & 1.56 & 1.46 & 0.85 & - & Ih1 & $2-3$ & $6-8$ & B, W & + & + \\
\hline P. domesticum & 259.2 & 3.3 & 4.3 & 0.90 & 0.99 & 0.93 & - & Ih 1 & $2-3$ & 8 & $\mathrm{~B}, \mathrm{Sb}$ & + & + \\
\hline P. cordatum & 208.0 & 5.3 & 4.4 & 1.34 & 1.08 & 0.75 & - & - & $2-3$ & $6-7$ & B & + & + \\
\hline P. erubescens & 264.7 & 4.8 & 3.9 & 1.11 & 0.94 & 0.83 & Ih1 & Ih1 & $1-2$ & $5-6$ & B & + & + \\
\hline P. erubescens 'Burgundy' & 306.0 & 4.8 & 3.8 & 0.96 & 0.94 & 0.88 & Ih1-2 & Ih1 & $1-2$ & $8-10$ & $\mathrm{~B}, \mathrm{Sb}$ & + & + \\
\hline P. imbe & 426.9 & 3.6 & 3.7 & 0.83 & 0.85 & 0.75 & $1-2$ & Ih1 & $2-3$ & 10 & $\mathrm{~B}, \mathrm{Sb}$ & + & + \\
\hline P. martianum & 463.7 & 9.3 & 5.8 & 0.79 & 1.16 & 0.87 & $1-2$ & $1-2$ & $2-3$ & 6 & $\mathrm{~B}$ & + & + \\
\hline P. microstictum & 444.0 & 5.3 & 5.7 & 1.21 & 1.32 & 1.12 & - & - & $2-3$ & $7-8$ & $\mathrm{~B}, \mathrm{Sb}, \mathrm{W}$ & + & + \\
\hline P. pedatum & 197.8 & 3.0 & 2.9 & 1.41 & 1.33 & 1.00 & - & Ih1 & $2-3$ & 6 & B & + & + \\
\hline P. squamiferum & 244.3 & 2.9 & 2.9 & 1.07 & 1.15 & 0.90 & - & - & $2-3$ & $5-6$ & B & + & + \\
\hline$P$. angustisectum & 187.8 & 2.8 & 2.2 & 0.89 & 1.13 & 1.09 & - & - & $2-3$ & $5-6$ & B & + & + \\
\hline P. lacerum & 218.6 & 2.5 & 2.2 & 1.52 & 1.12 & 0.88 & - & - & $1-2$ & $5-6$ & B & + & + \\
\hline P. pinnatifidum & 176.9 & 3.5 & 3.6 & 1.38 & 0.95 & 0.65 & - & Ih1 & $2-3$ & $6-7$ & B & + & + \\
\hline P. $\times$ corsinianum & 182.4 & 3.5 & 2.5 & 1.56 & 0.87 & 0.68 & Ih1-2 & - & $1-2$ & 6 & B & + & + \\
\hline P. 'Imperial Green' & 302.2 & 4.1 & 3.9 & 0.97 & 0.84 & 0.88 & Ih1-2 & Ih1 & $2-3$ & $8-10$ & B & + & + \\
\hline
\end{tabular}

Ad - adaxial epidermis, Ab - abaxial epidermis, ETI - epidermal thickness index, Ih1 - one, interrupted hypodermis layer, "-" - absence of hypodermis layer, + -presence of druses and styloids, B - biforine, Sb - thin-walled, spindle raphide cells, $\mathrm{W}$ - wide cells.

Philodendron stomata are abaxial, randomly oriented, brachyparacytic to brachyparahexacytic. Our studies show that the species of three subgenera of Philodendron have amphistomatic leaves with a strongly reduced density of stomata on the adaxial leaf surface. This conclusion is true and documented with SEM photographs. In T.S. the stomata were positioned at the same level of epidermal cells in all taxa. Significant differences are observed in the density of stomata. In the subgenus Meconostigma the mean density of stomata was 21 (per $\mathrm{mm}^{2}$ ), and in Pteromischum it was about 10. A much greater variation in this characteristic was recorded in the species from the subgenus Philodendron ranging from 4 to 21.5. KeATING (2002) reported several useful leaf anatomical characters for diagnostic use in 380 species and 105 genera of Araceae. The same author classifies the epidermal cell walls in the paradermal view as straight, undulate or extremely sinuous. In the Philodendron specimens analysed here straight and straight-slightly undulate cell walls were observed. KeATING (2002) stated that in some aroid genera the outline of the periclinal wall of the epidermal cells, as well as their height/width proportion, have diagnostic value for taxonomy. In most Philodendron taxa studied here the outer periclinal cell walls in both surfaces were flat, but in P. surinamense (subgenus Pteromischum), $P$. melanochrysum and P. hederaceum var. oxycardium (subgenus Philodendron) the outer periclinal walls were convex (papillate). Measurements of the thickness of the epidermis appeared to be useful for distinguishing Philodendron species. The general organisation of mesophyll tissue in vegetative organs has not been investigated in the subgenus Pteromischum (GraYum 1996) and Meconostigma (MaYo 1991). The overall structure of the leaves is described in the subgenus Philodendron by CROAт (1997). The mesophyll of Araceae is predominantly bifacial with a thicker spongy layer below the palisade. The spongy mesophyll in Philodendron has a distinctive structure in leaves with compacted cells and with air spaces (ENGLER 1920, Solereder \& MAYer 1928, Bunting 1968). Air spaces in spongy mesophyll were irregular in most species, but large cavities are observed in the midrib and in petioles. The palisade parenchyma cells were generally short. Our conclusions are identical. Measurements of leaf blade thickness appeared to be useful for distinguishing Philodendron species. In the Philodendron species studied the presence or absence of hypodermis could be a diagnostic character. Raphide and druse crystals are typical of the family Araceae. Keating (2003, 2004 a) for all the family described eight raphide types and in Philodendron five. In our study we found three types of raphides. One, two or 

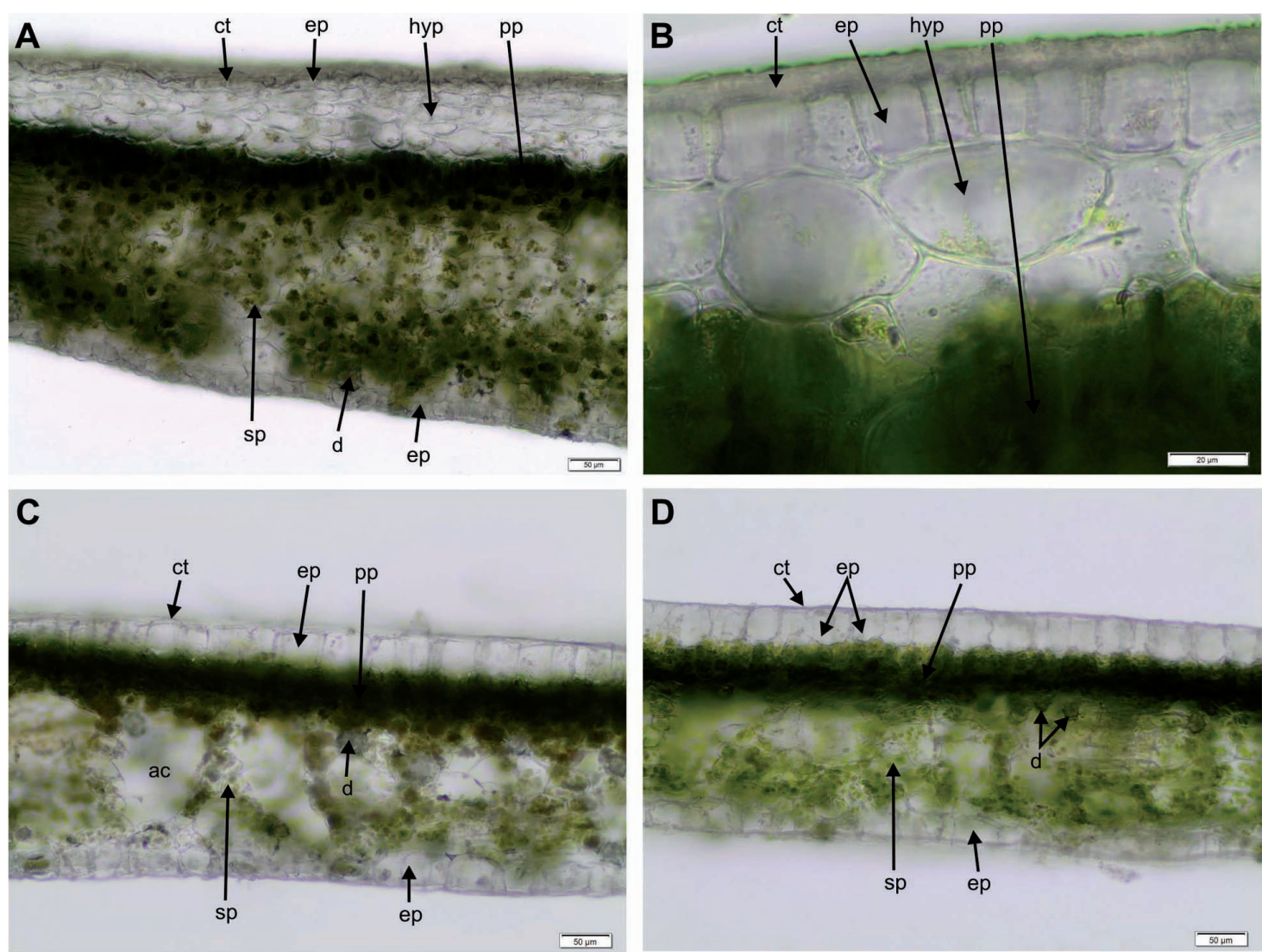

D
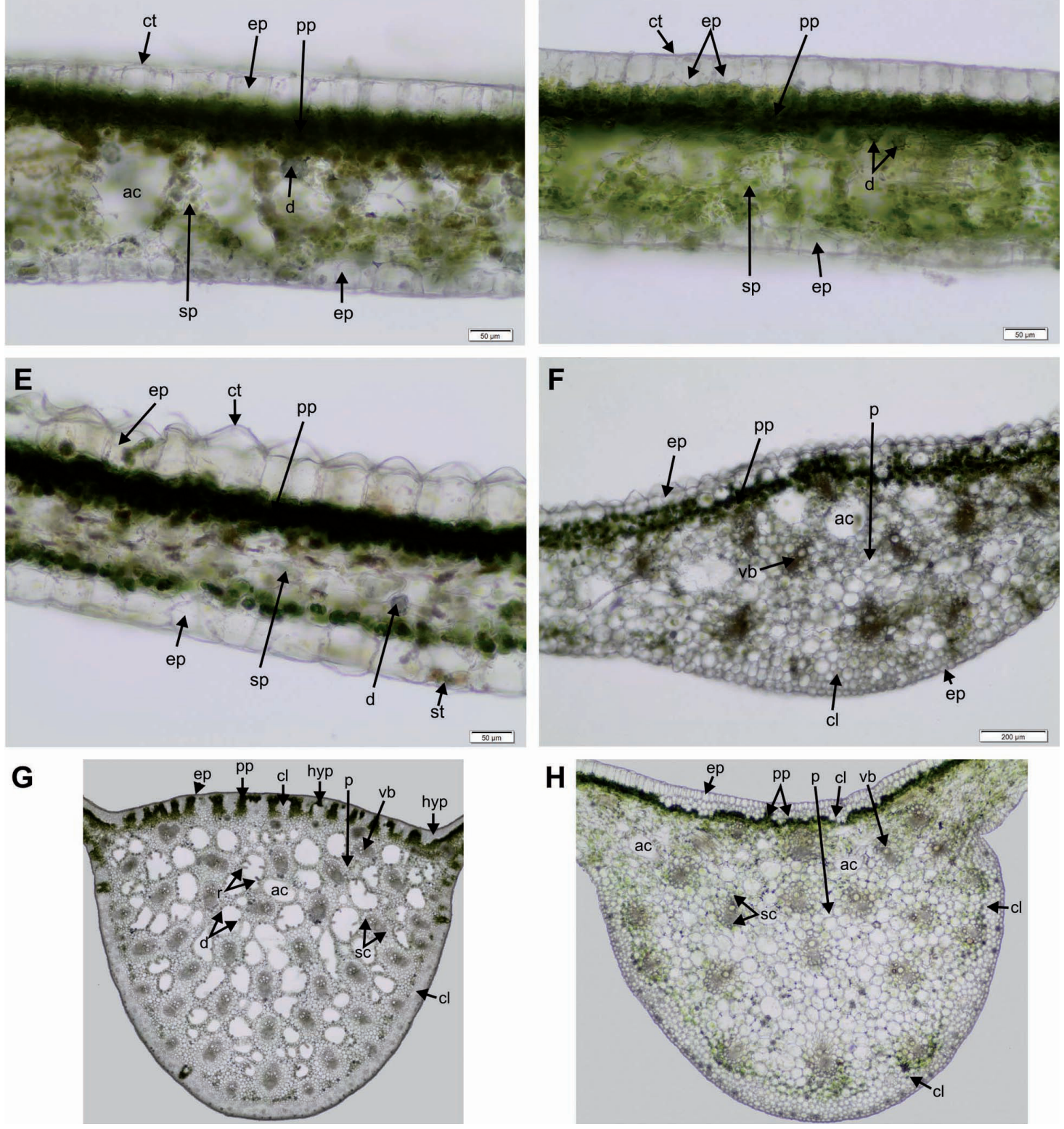

Fig. 6. Transverse section (T.S.) of lamina (A-E) and midrib (F-H) in some Philodendron taxa: A - P. bipinatifidium. The hypodermis has elongated cells, B - P. martianum. Detail of the epidermis with a thick cuticle, C $-P$. cordatum. Spongy mesophyll layer with air cavities, D - P. angustisectum, E - P. melanochrysum. Papillose adaxial epidermis, F - P. surinamense. Papilose adaxial epidermis on the midrib, $\mathrm{G}-P$. bipinatifidium, $\mathrm{H}-\mathrm{P}$. lacinatum. Vascular bundles with fiber phloem and xylem caps; ct - cuticle, ep - epidermis, hyp - hypodermis, pp - palisade mesophyll, sp - spongy mesophyll, d - druse, ac - air cavities, st - stoma, p - parenchyma, vb - vascular bundle, cl - colenchyma, sc - sclerenchyma, $\mathrm{r}$ - raphides 
three types of raphides can be found simultaneously on a single plant. The results of the occurrence, type and location of calcium oxalate crystals will be published separately. In Philodendron the outline of the petiole and the midrib on the adaxial surface, epidermis and lamina structure, mesophyll, sclerenchymatous cells, collenchyma and raphide crystals are of potential use as character states in phylogenetic analysis and may be potentially informative characters of systematic importance. The presence of raphides and leaves bifacial with petiole and lamina are proposed as plesiomorphs of the Araceae (MAYO et al. 1997). The results slightly support the classification of the genus Philodendron into three subgenera. The species from different subgenera and sections have some very similar characters. The present research suggests stem anatomy to be very useful in delimitation of the infrageneric taxa of the genus (TENORIO et al. 2012). In petioles and laminas many characters are present in all of them and may be typical of the genus. More morphological/anatomical and molecular data are needed to confirm the sectional affiliation of certain species.

\section{ACKNOWLEDGEMENTS}

We are grateful to Ilona Wysakowska for technical assistance and to Wojciech Klimko for assistance with computer data recording.

\section{REFERENCES}

Barabé D., Bruneau A., Forest F., Lacroix C. (2002): The correlation between development of atypical bisexual flowers and phylogeny in the Aroideae (Araceae). Plant Systematic and Evolution 232: 1-19.

BARTHLOtT W. (1990): Scanning electron microscopy of the epidermal surface. In: D. Claugher (ed.). Scanning electron microscopy in taxonomy and functional morphology. Systematic Association Special Vol. 41. Clarendon Press Oxford: 69-94.

BunTiNG G.S. (1968): Vegetative anatomy and taxonomy of the Philodendron scandens complex. Gentes Herbarium 10(2): 136-168.

CROAT T.B. (1985): Collecting and preparing specimens of Araceae. Annals of the Missouri Botanical Garden 72: 252-258.

Croat T.B. (1997): A revision of Philodendron subgenus Philodendron (Araceae) for Mexico and Central America. Annals of the Missouri Botanical Garden 84: 311-704.

Croat T.B., Bunting G.S. (1979): Standarization of Anthurium descriptions. Aroideana 2: 15-25.

Dilcher D.L., Daghlian C.P. (1977): Investigations of angiosperms from the Eocene of southeastern North America: Philodendron leaf remains. American Journal of Botany 64(5): 526-534.
Engler A. (1899): Beiträge zur Kenntnis der Araceae IX. 16. Revision der Gattung Philodendron Schott. Botanische Jahrbücher für Systematik 26: 509-564 .

Engler A. (1920): Araceae-Aroideae und Pistioideae. In: A. Engler (ed.). Das Pflanzenreich (IV. 23F ). Engelmann, Leipzig: 148.

Gauthier M.P.L., Barabe D., Bruneau A. (2008): Molecular phylogeny of the genus Philodendron (Ara(ceae): delimitation and infrageneric classification. Botanical Journal of the Linnean Society 156: 13-27.

Gonçalves E.G., Salviani E.R. (2002): New species and changing concepts of Philodendron subgenus Meconostigma (Araceae). Aroideana 25: 3-15.

Grau A. (1983:) Las epidermis foliares de las Araceas cultivadas en la ciudad de Tucuman y sus alrededors. Lilloa 36(1): 15-34.

Grayum M.H. (1990): Revision and phylogeny of the Araceae. Annals of the Missouri Botanical Garden 77: 628-697.

Grayum M.H. (1996): Revision of Philodendron subgenus Pteromischum (Araceae) for Pacific and Caribbean tropical America. Systematic Botany 47: $1-233$.

GREAR J.R.J. (1973): Observations on the stomatal apparatus of Orontium aquaticum (Araceae). Botanical Gazette 134: 151-153.

Keating R.C. (2000): Collenchyma in Araceae: Trends and relation to classification. Botanical Journal of the Linnean Society 134: 203-214.

KeAting R.C. (2002): Acoraceae and Araceae. In: M. Gregory, D.F. Cutler (eds). Anatomy of the monocotyledons. Vol. 9. Oxford University Press, New York.

Keating R.C. (2003): Leaf anatomical characters and their value in understanding morphoclines in Araceae. Botanical Review 68(4): 510-523.

Keating R.C. (2004 a): Systematic occurrence of raphide crystals in Araceae. Botanical Review 68(4): 510-523.

Keating R.C. (2004 b): Vegetative anatomical data and its relationship to a revised classification of the genera of Araceae. Annals of the Missouri Botanical Garden, St. Louis 91: 485-494.

Krause K. (1913): Araceae-Philodendroideae-Philodendreae-Philodendrinae. In: A. Engler (ed.). Das Pflanzenreich 60 (IV. 23Db). Engelmann, Leipzig $1-143$.

Mayo S.J. (1988): Aspectos da evolucao e da geografia do genero Philodendron Schott (Araceae). Acta Botanica Brasilica 1 (2): 27-40.

MAYO S.J. (1990): History and infrageneric nomenclature of Philodendron (Araceae). Kew Bulletin 45: 37-71.

Mayo S.J. (1991): A revision of Philodendron subgenus Meconostigma (Araceae). Kew Bulletin 46(4): 601-681. 
MAYo S.J., BOgner J., Boyce P.C. (1997): The genera of Araceae. Royal Botanic Gardens, Kew.

SAKURAgui C.M., MaYo S.J., Zappi D.C. (2005): Taxonomic revision of Brazilian species of Philodendron section Macrobelium. Royal Botanic Gardens, Kew 60: 465-513.

Sснотт H.W. (1832): Araceae. In: H.W. Schott, S. Endlicher (eds). Meletemata Botanica. Gerold, Vienna: 16-22.

Solereder H., Mayer FJ. (1928): Systematische Anatomie der Monokotyledonen. Verlag von Gebrüder Bornträger Buchhandlung, Berlin, Stuttgart.

Tam S.M., Boyce P.C., Upson T.M., Barabé D., Bruneau A., Forest F., Parker J.S. (2004): Interge- neric and infrafamilial phylogeny of subfamily Monsteroideae (Araceae) revealed by chloroplast trnL-F sequences. American Journal of Botany 91: 490-498.

Tenorio V., Sakaragiui C.M., Vieira R.C. (2012): Stem anatomy of Philodendron Schott (Araceae) and its contribution to the systematics of the genus. Plant Systematic and Evolution 298(7): 1337-1347.

TURPIN P.J.F. (1836): Observations sur les biforines, organes nouveaux situés entre les véscicles du tissu cellulaire des feuilles dans un certain nombre d'espèces végétales appartenant à la famille des Aroidées. Annales des Sciences Naturelles, Botanique 2: 5-27. 